DOI: $10.2478 / \mathrm{v} 10122-011-0009-2$

\author{
A R T I C LES
}

\title{
DEVELOPMENT OF ASPECT AND TENSE IN SEMITIC LANGUAGES: TYPOLOGICAL CONSIDERATIONS
}

\author{
VIT BUBENIK
}

\begin{abstract}
Vit Bubenik. Development of Aspect and Tense in Semitic Languages: Typological considerations. Lingua Posnaniensis, vol. LIII (2)/2011. The Poznań Society for the Advancement of the Arts and Sciences. PL ISSN 0079-4740, ISBN 978-83-7654-173-0, pp. 7-23.

A survey of pertinent literature reveals that many studies of aspect in Semitic languages do not pay a due attention to the crucial theoretical distinction of perfect and perfectivity. In this paper I will adopt the 'chronogenetic' model of the morphosyntactic development of tense and aspect tested for the IndoEuropean languages (Hewson \& BUBENIK 1997) that allows five major aspectual categories to be distinguished (prospective, inceptive, imperfective, perfective, perfect) within 'Event Time'. I will argue that the appearance in Arabic of the analytic double-finite perfect (of the type kun-tu katab-tu 'I had written') was the most significant innovation during the New Stage not to be found in the other Central Semitic languages. During the Middle Stage in Mishnaic Hebrew and Middle Aramaic the canonical progressive aspect was paradigmatized while Classical Arabic created its double-finite counterpart

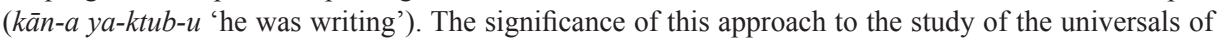
tense and aspect will be evaluated.
\end{abstract}

Vit Bubenik, Memorial University of Newfoundland, St. John's, Canada

A number of specialized studies of tense and aspect in Semitic languages are available (Cohen 1989; Eisele 1999, 2005; Fleisch 1957; KuryŁowicz 1973; Woidich 1975, and other) and yet it is not easy for a non-specialist to form a coherent picture of their nature let alone of their historical development. In Section 2. I propose to take a fresh look at these issues in terms of our cognitive model for the study of tense and aspect in Indo-European languages (Hewson \& BuBENIK 1997). I will address some of the theoretical problems surrounding the use of the terms "perfect" and "perfective" and the suitability of the latter term for Semitic linguistics. In Section 3, I will establish the three-way aspectual system of the Old Stage (represented by Akkadian Imperfective - Completive - Perfect) as a starting point for our analysis in Section 4 of typological changes which took place during the Middle Stage (the rise of the progressive aspect with tense distinctions marked by the copula in Middle Hebrew and Aramaic). In Section 5. I will discuss the appearance of the analytic double-finite perfect in Arabic (of the type kuntu katabtu 'I had written') at variance with the other two Central Semitic languages (Hebrew and Aramaic) and further differentiation of the imperfective category in Arabic (the rise of the progressive and habitual aspect) will be examined. The typological trajectory from the Old Stage dominated by aspect via Mid- 
dle Stage where we witness the rise of temporal distinctions implemented by the copula to a tense-prominent system of Arabic with two basic grammatical aspects (progressive and perfect) in three tenses will be summarized in Section 6.

\section{TENSE AND ASPECT IN SEMITIC LANGUAGES}

The system of 'tenses' in Central Semitic languages - as best known from Classical Arabic and Biblical Hebrew - is based on two morphological categories, called in most Western manuals (e.g. in widely used ABU-CHACRA 2007) perfect tense (formed by suffixes) and imperfect tense (formed by prefixes and suffixes): katab-a 'he wrote/has written' and $y a-k t u b-u$ 'he writes/will write', respectively. This traditional Latin-based terminology is far from being satisfactory for Semitic languages since Latin distinguishes three temporal forms in two aspectual subsystems, called traditionally Infectum (Present, Imperfect, Future) versus Perfectum (Perfect, Pluperfect, Future Perfect). In more up-to-date linguistic studies (ComRIE 1991; Fischer 2002; Bateson 2003) it is customary to refer to the two Semitic forms by twofold labels Past/Perfective versus Non-Past/Imperfective, indicating that these two forms express both aspect (perfective vs. imperfective) and tense (past vs. non-past).

One of the fundamental problems in the analysis of the system of Classical Arabic is the polysemy (double function) of the basic form katab-a 'he wrote' or 'he had written'. As my translation indicates this form could be labeled both preterite (Past) and pluperfect. Similarly in Biblical Hebrew $k \bar{a} \underline{t} a \underline{b}$ of the original Hebrew text covers the scope of both the past perfective (Aorist) and the perfect in the Greek translation (Septuagint): é-grap-s-e 'he wrote' and gé-graph-e 'he has written' (All the functions of Hebrew kāta $\underline{b}$ have recently been surveyed by ANSTEY 2009). A serious terminological confusion is seen in the use of the term perfect for the perfective. The term imperfective is a major improvement over the traditional latinate term Imperfect (where it represents past imperfective). It represents a highly suitable label for $y a-k t u b-u$ in its use for both the incomplete (habitual) events in the present 'he writes' or the imagined events located in the future time zone, 'he will write', which are by their own nature incomplete, i.e. imperfective. On the other hand, to keep the traditional label Perfect for perfective is most undesirable in spite of its widespread use in Arabic and Hebrew linguistic studies. This problem becomes even more acute when dealing with Akkadian which distinguishes three aspectual categories labeled by tense terms Present - Preterite - Perfect in the influential grammar of Akkadian by von Soden (1952). LiPIŃSKI (2001: 345) uses the "convenient" terms imperfective and perfective (instead of Present and Preterite) but his definition of the perfective category confuses perfective with perfect ("it expresses $[\ldots]$ the completed (perfect) $[\ldots]$ aspect of the action"). In semantic terms, however, he correctly characterizes the grammatical opposition of imperfective versus perfective as "incomplete" versus "completed".

BRUSTAD (2000: $165 \mathrm{ff}$.) argues that ComRIE's (1976) three "crosslinguistic" aspectual categories, imperfective, perfective and perfect, are realized in Arabic as the "morphological forms" of the verb imperfective, perfective and participle (both active and passive participles can carry "perfect aspect"). In typological terms she observes that Slavic languages grammaticalize perfective and imperfective aspect in a "more elaborate system" than Arabic (and that English has a perfect which is similar to the Arabic), but in spite of their morphological 
diversity she maintains that it must be shown that the meanings of these Arabic forms "conform" to general linguistic definitions of Comrie's three aspect. A propos the perfective she maintains that the Slavic perfective is highly "punctual" while that of the Arabic perfective appears to be more focused on the "completed nature" of the event. Similarly, MitcheLL and EL-Hassan (1994: 8) suggest that the "fulfilled, accomplished" nature of the perfective category is "at the root of Arabic distinctions of tense and mood".

However, it has to be made clear that the nature of the opposition of perfectivity in Central Semitic languages (based on the opposition of suffixal versus prefixal conjugation) is very different from the nature of perfectivity as familiar from several families of the Indo-European phylum, most notably Hellenic and Slavic. As argued by CoHEN (1989), the term perfective if used for aspectual contrasts in languages as diverse as Slavic, Greek and Arabic is unsatisfactory. The fundamental difference between West and East Slavic systems (expressing the perfectivity by preverbs) and Semitic is the fact that the derivational processes in Slavic create new lexical items (e.g. Russian on pisá-l 'he writes' versus na-píš-et' 'he will write' while in Semitic the opposition of "accomplissement" is realized by means of two different conjugations "à l'intérieur du même verbe" (p. 170). In Greek the perfective category is realized by the aorist (to be discussed under). In Semitic Cohen operates with a binary contrast of "accompli" (completive) versus "inaccompli" (incompletive). I will address this issue in another theoretically oriented paper (forthcoming); in this historically and typologically oriented paper I will keep the established grammatical term perfective for Slavic and Greek, and will adopt the semantic term completive (Cohen's "accompli") for the binary systems of Arabic and Hebrew. Instead of the infelicitous (in English) term incompletive I shall keep the more or less satisfactory term imperfective.

It is normal in modern TA studies to distinguish between grammatical and lexical aspect (also called Aktionsart), and to distinguish three major lexical aspects: states, activities and accomplishments in the well-known terminology of VENDLER (1967: 97ff). These three, for example, may be seen in Eisele's influential study of Cairene Arabic (1999, 2005), using a somewhat different terminology. It is universally recognized, in other words, that grammatical aspects interact constantly with lexical aspects, and that a full and proper aspectology must deal with both, and with the various ways in which they interact.

In the following expose it will be important to keep in mind the diachronic dimension of my inquiry to avoid unjustifiable anachronisms. Following DiAKONOFF (1988:17 ff.) I will allocate the individual Semitic languages to three stages: Old (or Ancient) Middle and New (or Late) Stage.

\section{COGNITIVE APPROACH TO THE STUDY OF TENSE IN SEMITIC}

In what follows I will tackle the whole issue of Semitic aspect from a different perspective of cognitive linguistics which we developed in our systemic analysis of tense and aspect in Indo-European languages (HEWson \& BUBENIK 1997). We represent major aspectual categories as cardinal positions within "Event Time" (op. cit., p. 14) as in (1) below, where the square brackets represent the initial ([) and final (]) moments of the event. In this diagram the subject may be represented as occupying one of five different positions, labeled A, B, C, D, E. In this way A represents the subject in a position before the event (prospective aspect); 
forms. Akkadian and Arabic distinguish active vs. passive participles, and display several Aktionsart categories in their quasinominal systems (i.e. there are iterative, frequentative and causative participles and verbal nouns/infinitives) but they do not possess a three way aspectual contrast of the imperfective versus perfective versus perfect participle (as in Greek gráph-ōn 'writing' versus gráp-s-ās 'having written' versus ge-graph-ós 'having written'). Only Akkadian, the most archaic Semitic language, possess here a binary contrast of the imperfective versus perfect participle $(p \overline{a r i s}-u(m)$ 'separating' versus mu-p-ta-rs-u(m) 'having separated'). Similarly, the three-way aspectual contrast found with the Greek infinitive has no counterpart in Semitic; only in Akkadian there is the binary contrast of the verbal

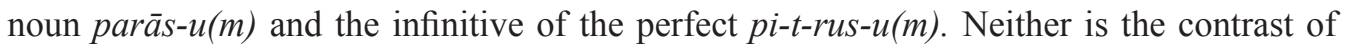
perfectivity found in modal forms in Akkadian. The forms expressing the wish (so-called 'precative' in the grammars of Akkadian, corresponding to the Greek optative) are available only in the completive and the stative categories: $l=i p r u s(<l \bar{u}=i$-prus) 'may he separate, decide' versus $l \bar{u}=$ balit ' may he live'.

In the indicative, the Akkadian system is based on a three-way aspectual contrast of Imperfective, Completive and Perfect: i-parras 'he separates', i-prus 'he separated' and $i$-p-ta-ras 'he has separated' (in CoHEN's terminology (1989: 172-173) "présent inaccompli", "prétérit accompli" and "parfait accompli"). Compared with Ancient Greek (and other IE languages such as Sanskrit) with a binary contrast of tense operating on their three-way aspectual systems, in Akkadian there were no temporal contrasts as shown in (3), i.e. the whole verbal system was based on three aspects (in practical terms, the imperfective $i$-parras meant not only 'he separates' but also 'he will separate'), and the completive functioned also as the pluperfect ('he had separated'). The perfect formed by the infix -ta- expresses past events with lasting results (very much like the perfect in IE languages): attardakkum < at-t-ard-am-kum 'now I have sent to you'. The fourth aspectual category, 'stative' (cf. von SODEN 1952: 100) was actually the adjective finitized by means of pronominal clitics (damq$\bar{a} k u$ 'I am good', damq-äta 'you (M) are good', damiq 'he is good'):

\begin{tabular}{|c|c|c|c|c|}
\hline Indicative & $\begin{array}{l}\text { Imperfective } \\
\text { i-parras } \\
\text { 'he separates' } \\
\sim \text { 'he will separate' }\end{array}$ & $\begin{array}{l}\text { Completive } \\
\text { i-prus } \\
\text { 'he separated' } \\
(\sim \text { 'he had separated') }\end{array}$ & $\begin{array}{l}\text { Perfect } \\
\text { i-p-ta-ras } \\
\text { 'he has separated' }\end{array}$ & $\begin{array}{l}\text { Stative } \\
\text { damiq } \\
\text { 'he is good' }\end{array}$ \\
\hline Precative & & $1=\mathrm{i}$-prus & & lū baliṭ \\
\hline (=optative) & & 'may he separate' & & 'may he live' \\
\hline Participles & pāris-u(m) & & mu-p-ta-r-su(m) & \\
\hline Infinitives & parās-u(m) & & pi-t-rus-u(m) & \\
\hline
\end{tabular}

Before addressing the issue of the rise of the progressive aspect in Central Semitic languages during their Middle Stage by means of the analytic constructions combining the copula and the participle (Section 4.), it should be observed that Akkadian never grammaticalized its verbum existentiae (baš $\hat{u}$ 'to be') as an auxiliary. Instead, it further differentiated its basic aspectual system by means of the derivational infix -tan- (inserted after the first radical) as shown in (4): 


\begin{tabular}{llll}
\multicolumn{2}{c}{ Iterative/habitual counterparts to the basic aspectual categories in Akkadia } \\
& Iterative/Habitual & Iterative/Completive & Iterative/Perfect \\
Indicative & i-p-tan-arras & i-p-tan-ras & i-p-ta-tan-ras \\
& 'he keeps s.-ing' & 'he kept s.-ing' & 'he has been separating' \\
Participle & mu-p-tan-ris-u(m) & & mu-p-ta-rris-u(m) \\
Infinitive & pi-tan-rus-u(m) & & pi-ta-rrus-u(m)
\end{tabular}

A propos the grammatical category of stative, one has to keep in mind that there also inherently stative verbs and that there is major difference between non-stative (i.e. active) verbs and stative verbs with respect to the imperfective category. With non-stative (active) verbs the meaning can be either present or future, with stative verbs, however, the imperfective category has the meaning of the inceptive/ingressive aspect: $i$-dammiq 'he will be good' while the present 'he is good' is expressed by the stative damiq (the stative is actually identical with the adjective damq- $u$ 'good'(Masc) with the form damiq seen in the feminine form damiq-tu). The stative could be formed not only from adjectives (and nouns $b \bar{e} l-\bar{e} k u$ 'I am the lord') but also from fientive (eventive) verbs: $\bar{a} l$-a (ACC) šakānum 'to found the city' $\bar{a} l-u(\mathrm{NOM}) \check{s}$ akin 'the city was/has been/is founded'; but there are quite a few transitive verbs whose stative possesses active meaning (see von SodEn 1952: 100 ff.), e.g. sabātum 'to grasp' maxārum 'to receive': maxir 'he is the one who has received', 'he is the reciever'. Here Akkadian anticipates the rise of the so-called 'neo-perfect' in Central Semitic languages: naxlapta labš- $\bar{a} k u$ (Stative) 'I am the one who has put the shirt on' > 'I have put [my] shirt on', Hebrew lābaš-tī (Completive) kuttont- $\bar{l}$ 'I have put my shirt on', Arabic labis-tu (Completive) qamīṣ- $\bar{\imath}$ 'I have put my shirt on'.

The completive category (called "preterite" in the grammars of Akkadian) expresses past completed events and the perfect is used for the past events with present relevance (in Classical Babylonian letters especially after the adverbs inanna and anumma 'now'; for details see VON SODEN 1952). The completive category is also used modally as precative and cohortative: l-iblut 'may he live', $i$ nidbub 'let us speak'), and so is the imperfective category in the formation of the prohibitive: lā tapallax 'don't be afraid' (cf. the formation of the prohibitive on the basis of the imperfective aspect in Slavic languages). Outside modal constructions the completive in Akkadian was limited to the expression of past completed events and was never used for future time reference - this function was the domain of the imperfective. The distinction between completive and jussive in Proto-Semitic was implemented by accent: *yá-prus 'he separated' versus *ya-prús, 'may he separate', respectively (see Hetzron 1969).

\section{MIDDLE STAGE IN SEMITIC}

This state of affairs changed fundamentally during the Middle and New Stages of Semitic languages represented by Mishnaic Hebrew, Middle Aramaic and Classical Arabic. The Proto-Semitic stative ( $\mathrm{CaCiC}$-, preserved in Akkadian damiq 'he is good') became the source of the (so-called) 'neo-perfect' which ended up as the perfective category ( $k \bar{a} \underline{t} a \underline{b}$ and katab- $a$ 'he wrote') in Hebrew and Aramaic; during the New Stage and new perfect was created by analytic means in Classical Arabic. 
In both Hebrew and Arabic - in the absence of the perfect (available in Akkadian) the completive was used to express both the completed past events and the past events with present result (perfect): Hebrew gādal-tā, Arabic kabur-ta 'you were/are great'. Stative verbs in Hebrew and Arabic are marked (not consistently) by the second vowel $-u$ - or $-i$ - (Hebrew qātōn '(he was) small' < *qațun, kāb $\underline{\bar{e}} \underline{d} \underline{\text { ' }}$ '(he was) heavy'<*kabid) versus - $a$ - of fientive (eventive verbs) but otherwise they are completely incorporated into the binary conjugation of the completive and imperfective. The meaning of the present perfect is found typically with verbs of resultant state: Hebrew $y \bar{a} \underline{d} a \xi-t \bar{l}$, Arabic $S a r a f-t u$ 'I know' (cf. the present perfect in Greek é-gnō-ka and Latin $n \bar{o} v-\bar{l}$ 'I learnt' >' I know'),

There are also numerous examples of the completive category used for future time reference, both perfective and imperfective; in Biblical Hebrew some of them are classified as "prophetic future" (cf. RogLAND 2003):

$$
\begin{aligned}
& \text { hā= =ām } \quad \text { ha=hōləkīm } \quad \text { b=a=hōšek } \quad \text { rāPū } \quad \text { Pōr gādōl } \\
& \text { the people the walking }+\mathrm{PL} \quad \mathrm{in}=\text { the }=\text { darkness } \quad \text { see }+ \text { COMPL }+\mathrm{PL} \text { light great } \\
& \text { 'The people walking in the darkness will see the great light' } \\
& \text {... kī Piššərūnī bānōt } \\
& \text { because call-happy }+ \text { COMPL }+3 \mathrm{PL}=\text { me daughters } \\
& \text { '(Happy am I!) For the young women will (be) call(ing) me happy' }
\end{aligned}
$$

This strategy was systematized in the peculiar Sequence of Tenses to be exemplified in (13)-(16).

In Classical Arabic the completive can be used for future time reference after the adverbial $m \bar{a}$ 'as long as, soon':

$$
\begin{aligned}
& \text { rubba=mā } \text { ৎud-tu Pilay=ka baৎda qalīlun (al-Manfalūṭī; in CANTARINo 1974: 62) } \\
& \text { often return+COMPL+1SG to=you after a while } \\
& \text { 'Perhaps I shall return to you soon' }
\end{aligned}
$$

During the Middle and the New Stage, Central Semitic languages rebuilt the old aspectual system (as represented by Akkadian) by analytic means. The major innovation was the rise of the analytic imperfective aspect whose meaning could be habitual (iterative, frequentative) or continuous (progressive). In Old (Biblical) Hebrew the imperfective aspect could be expressed by the two polysemous categories of the Imperfective and Completive:

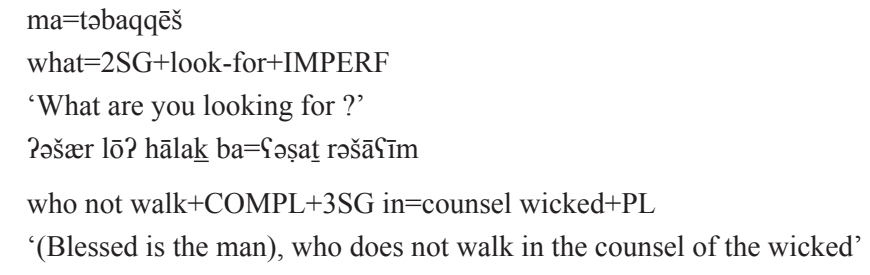

\section{'(Blessed is the man), who does not walk in the counsel of the wicked'}

[Gen 37.15]

During the later periods represented by Mishnaic Hebrew (of the 2nd c. BCE) and Middle Aramaic (represented by the Targumim and the two Talmuds of the $2 \mathrm{nd}-6$ th c. CE) this state of affairs was changed by the rise of the analytic morphology of the impefective aspect. Two different strategies were used. Hebrew created the canonical progressive construction by using the copula in combination with the present participle, while Middle Aramaic attached 
pronominal clitics to it. In Mishnaic Hebrew this strategy allowed for the formation of the progressive aspect in the past and future time zones, with the completive form of the copula and the present participle for the past events ( $h \bar{a} y-\bar{a} h k \bar{o} t \bar{e} b_{.}$'he used to write, he was writing'), and most notably the combination yihyēh kōtēe ' he will be writing', featuring the imperfective form of the copula grammaticalized as the future tense auxiliary, for the forthcoming events:

$$
\begin{array}{ll}
\text { Progressive aspect in Middle (Mishnaic) Hebrew } \\
\text { Present } & \text { hū kōtēẹ 'he [is] writing' } \\
\text { Past } & \text { hāy-āh kōtēe } \underline{b} \text { 'he used to write, he was writing' } \\
\text { Future } & \text { yi-hyē kōtē } \underline{\text { ' }} \text { 'he will be writing' }
\end{array}
$$

Pertinent examples from Mishnaic Hebrew are given in (9):

$$
\begin{aligned}
& \begin{array}{ll}
\begin{array}{l}
\text { hāy- } \bar{u} \\
\text { were+3Pl }
\end{array} & \begin{array}{l}
\text { Pōmər-īn } \\
\text { saying+Pl }
\end{array}
\end{array} \quad \text { [Mishnaic Hebrew, after SEGAL 1958: 156-157] } \\
& \text { 'they used to say' }
\end{aligned}
$$

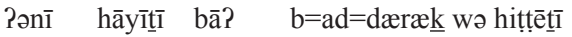

$$
\begin{aligned}
& \text { I was going by }=\text { the }=\text { road and inclined }+1 \mathrm{SG} \\
& \text { 'I was going by the road and inclined' }
\end{aligned}
$$

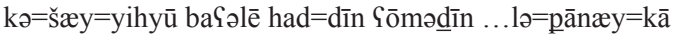

$$
\begin{aligned}
& \text { when }=\text { will be }+3 \text { PL masters the }=\text { law standing }+P L \text { to }=\text { face }=\text { your } \\
& \text { 'when the litigants will be standing before you' }
\end{aligned}
$$

The same formations are also available in the imperative and infinitive:

$$
\begin{aligned}
& \text { həwē məqabbēl versus qabbēl [Mishnaic Hebrew] } \\
& \text { be+IMP receiving receive+IMP } \\
& \text { 'receive (regularly)!' 'receive!' }
\end{aligned}
$$

\begin{tabular}{|c|c|}
\hline Jewish Babylonian Aramaic & Hebrew (Old) \\
\hline$(\mathrm{ka}=) \mathrm{katev}=\mathrm{na}$ 'I write (habitually)', 'I am writing' & Pənī kōtēe $\underline{b}$ \\
\hline$(\mathrm{ka}=) \mathrm{katv}=\mathrm{at} \quad$ 'You write', 'You are writing' & Pattāh kōtēe $\underline{b}$ \\
\hline$(\mathrm{ka}=) \mathrm{katv}+\mathrm{in}=\mathrm{an}$ 'We write', 'We are writing' & (Pə)naћnū kōtob $\underline{b}+\underline{\overline{1} m}$ \\
\hline$(\mathrm{ka}=) \mathrm{katvi}^{+}=\mathrm{tu}(\mathrm{n})$ 'You $(\mathrm{Pl})$ write', 'You $(\mathrm{Pl})$ are writi & Pattæm kōtəo $\underline{b}+\overline{1} m(\mathrm{Pl} / \mathrm{M})$ \\
\hline
\end{tabular}

(cf. Russian imperfective pri-nim-áj versus vs. perfective imperative $p r i$-mí)

$\begin{array}{lll}\text { hæ= }=\text { hāšū } & \text { lihyōt } & \text { mōkēer } \\ \text { the=suspected } & \text { to=be+INF } & \text { selling }\end{array}$

'he who is suspected to be selling'

Unlike Mishnaic Hebrew Middle Aramaic finitizes its present participle (Old Aramaic $k \bar{a} \underline{t} \overline{\underline{b}} \underline{b}$ 'writing') by personal clitics. Examples in (11) are taken from the Babylonian Talmud (quoted after NosEK 2001):

Finitization of the present participle by personal clitics in Jewish Babylonian Aramaic (of Babylonian Talmud)

The preceding particle $k a=$ resulted by a grammaticalization of the participle of the verb $q \bar{u} m$ 'rise, stand up' $(q \bar{a} \mathrm{~T} \bar{e} m>q \bar{a} \mathrm{P} \bar{e}>q \bar{a}>k a)$

Combined with the copula in the past this periphrastic formation can express a habitual or progressive aspect. At variance with Hebrew there need not be agreement in person and gender (but agreement in the plural is observed): 


\begin{tabular}{|c|c|c|c|c|}
\hline \multicolumn{2}{|c|}{ Jewish Babylonian Aramaic } & & \multicolumn{2}{|c|}{ Mishnaic Hebrew } \\
\hline hav-a & yatev & 'he used to sit' & hāy+āh & yōšēb \\
\hline was $+M$ & sitting $+\mathrm{M}$ & & was $+\mathrm{M}$ & sitting $+\mathrm{M}$ \\
\hline hav-a & yatv-a & 'she used to sit' & hāyəțtāh & yōšə $\underline{b}+\bar{a} h$ \\
\hline was $+M$ & sitting $+\mathrm{F}$ & & was $+\mathrm{F}$ & sitting $+F$ \\
\hline hav-a & $\mathrm{ka}=\mathrm{amej}=\mathrm{na}$ & 'I used to say' & hāyīit $\underline{1}$ & ?ōmēr \\
\hline was $+M$ & $\mathrm{PRT}=$ saying $+1 \mathrm{SG}$ & & was $+1 \mathrm{SG}$ & saying $+\mathrm{M}$ \\
\hline hav-o & $\mathrm{ka}=\mathrm{azl}-\mathrm{i}$ & 'they were going' & hāy+ū & hōlək+īm \\
\hline vere+3PL & $\mathrm{PRT}=$ going $+\mathrm{PL}$ & & were $+3 \mathrm{PL} / \mathrm{M}$ & going +PL/ \\
\hline
\end{tabular}

A well-known a morphosyntactic 'peculiarity' of Biblical Hebrew is the use of the completive category for future time reference in the narratives introduced by the imperfective; this so-called "consecutive perfect" is introduced by the conjunction wa 'and":

$$
\begin{aligned}
& \text { yišlah malPāk̄ō wə-hislī } \\
& \text { 3/SG/M+send+IMPF angel=his and make-prosper }+\mathrm{COMPL}+3 / \mathrm{SG} / \mathrm{M} \text { way=your } \\
& \text { 'He will send his angel and make your way prosper' }
\end{aligned}
$$

The accentual difference between the ordinary completive and its consecutive variety is observable only in the 1 st and $2 \mathrm{nd} \mathrm{Sg}$. That is in the dialogue projecting a sequence of events into the future time zone the first event is realized by the imperfective category; if the following event is expressed by the completive category its accent is placed on the last syllable. The completive used in its meaning of the past completed event is always accented

\begin{tabular}{|c|c|c|c|}
\hline $\begin{array}{l}\text { Səlē Pittī... } \\
\text { come-up+II }\end{array}$ & $\begin{array}{c}\text { wə=nillāhəmāh ... wə } \quad \text { wālakt } t^{\prime} \overline{1} \\
\text { Pand }=1 \text { Pl+fight+IMPF and }=\text { go+COMPL+1SG }\end{array}$ & $\begin{array}{l}\text { gam Pən̄̄ } \\
\text { also I }\end{array}$ & [Judges 1.3] \\
\hline
\end{tabular}
on the penultimate. Contrast:

As we saw above, there are also examples of the completive category used for future time reference outside the narratives:

$$
\begin{aligned}
& \text { wat=tōmer lêpā bə=Pošrī } \quad \text { kī Piššərū=nī bānōt } \quad \text { [Gen 30.13] } \\
& \text { and }=3 / \mathrm{SG} / \mathrm{F}+\text { say }+\mathrm{IMPF} \quad \text { Leah in=happiness }=\text { my for } \quad \text { call }+\mathrm{COMPL}+3 / \mathrm{PL}=\text { me daughters } \\
& \text { 'And Leah said: "Happy am I" for the daughters will call me happy' }
\end{aligned}
$$

Vice versa, the imperfective can be used to refer to the past events in the narratives introduced by the completive; this so-called "consecutive imperfect" is introduced by the proclitic conjunction $w a=$ followed by the reduplication of the initial consonant of the personal prefix:

$$
\begin{aligned}
& \text { b=ay=yāmīm hā=hēm } \\
& \text { in }=\text { the }=\text { days } \quad \text { the }=\text { those } \\
& \text { ћālāh } \\
& \text { hizqiyyāhū ... } \\
& \text { way=yābōo? } \\
& \begin{array}{l}
\text { become-sick+COMPL+3/S }+ \text { yəšąyāhū } \\
\text { Pēlāw }
\end{array} \\
& \text { and }=3 / \mathrm{SG}+\mathrm{IMPF}+\text { come } \\
& \text { to=him Isaiah }
\end{aligned}
$$

[2 Kings 20.1] 
The "consecutive imperfect" is distinguished from the ordinary imperfective by its accent: $w a y=y \underline{i}-\underline{k} t \bar{o} \underline{b}$ 'and he wrote' versus imperfective $w \partial-y \underline{i} \underline{k} t^{\prime} \bar{o} \underline{b}$ 'and he will write' (with accent on the ultima). The form of the consecutive imperfective with the penultimate accent was inherited (cf. Hetzron's 1969 reconstruction of the Proto-Semitic perfect *yá-qtul versus jussive *ya-qtúl). On the other hand, desinential accent in the 1 st and 2 nd $\mathrm{Sg}$ in the consecutive perfect is an innovation of Old Hebrew. The system of consecutive tenses of Old Hebrew has its roots in the so-called 'syndetic parataxis' which is documented across the broad spectrum of Semitic languages. Von SodEN (1952: 209) provides an example from Old Babylonian where the perfect $i$ - $p$-t-aras may follow after the completive (his 'preterite') $i$-prus in the narration of consecutive events:

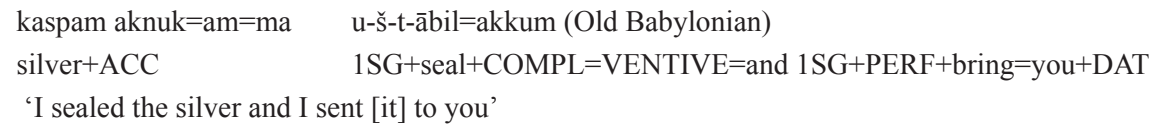

Here the choice of the perfect form $u-\check{s}$-t-ābil=akkum (instead of the completive $u-\check{s}$ $\bar{e} b i l=a k k u m$ ) indicates that the action "sending the silver" followed the action of "sealing" (with the modal nuance of the "immediate purpose" of sealing it). During the later periods similar instances of the use of two different aspectual forms for sequencing the events in the past are also available from Classical Arabic:

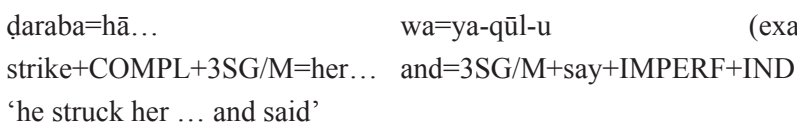

After the conjunction $f a=$ 'and', however, the completive is used to imply that the second action results from the previous one:

$$
\begin{array}{ll}
\begin{array}{l}
\text { darabtu }=h \bar{u} \\
\text { strike }+C O M P L \\
\text { 'I beat him, so that he cried' (i.e. ... so that he cried') }
\end{array}
\end{array}
$$

Old Hebrew went farthest in its systematization of the syndetic parataxis to make up for the 'deficiency' in expressing the three-way temporal distinctions by means of the simple binary aspectual system (of imperfective versus completive). The demise of the old system of the consecutive "perfect" and "imperfect" in Mishnaic Hebrew was also precipitated by the fact that the marking for basic temporal contrasts had to rely too much on the accentual differences. The rise of the Mishnaic system of the analytic formations exploiting the auxiliaries $h \bar{a} y \bar{a} h$ 'he was' and yihyêh 'he will be' in conjunction with the participle solves this problem in an 'elegant' fashion. The appearance of an unambiguous periphrastic future tense and the reduction of the polysemy of the inherited completive allow us to portray the Mishnaic system as a tense-prominent versus the old syncretic aspect-prominent system of Old Hebrew; to put it succinctly, the old aspect-prominent system was temporalized. To quote LIPIŃSKI (2001: 354) a propos “modern" Semitic languages: "While the «classical» verbal system of the Semitic languages is based on aspect, modern speech tends to found the verb inflection on the notion of time and to express it by means of «tenses»." 
(20)

(21)

\begin{tabular}{|c|c|c|}
\hline & $\begin{array}{l}\text { Imperfective } \\
\text { (Present, Future) }\end{array}$ & $\begin{array}{l}\text { Completive } \\
\text { (Past) }\end{array}$ \\
\hline & yi-kt $t^{\prime} \underline{o} \underline{b}$ & kātáb $\underline{b}-\mathrm{t} \overline{1}$ \\
\hline & 'he writes, will write' & 'I wrote' \\
\hline \multirow[t]{2}{*}{ Consecutive tenses } & $\mathrm{w} \partial=\mathrm{k} \bar{a} \underline{t a b} \underline{b}-\mathrm{t}^{\prime} \overline{1}$ & way=yíktōb $\underline{b}$ \\
\hline & 'and I will write' & 'and he wrote \\
\hline
\end{tabular}

Tense-prominent system of Mishnaic Hebrew

\begin{tabular}{|c|c|c|c|}
\hline & Present & Past & Future \\
\hline Imperfective & kōtēēb yi-kt $t^{\prime} \underline{o} \underline{b}$ & & yi-kt' $\underline{o} \underline{b}$ \\
\hline $\begin{array}{l}\text { Habitual/Progressive } \\
\text { Completive }\end{array}$ & kōtēêb & $\begin{array}{l}\text { hāyāh kōtēēb } \\
\text { kātab } \underline{ }\end{array}$ & yihyēh kōtēē $\underline{b}$ \\
\hline
\end{tabular}

In Ethio-Semitic Geez the morphology of the imperfective category yo-kattzb, comparable with the Akkadian imperfective $i$-parras, represents a remarkable archaism in its exploitation of the reduplication of the second radical (its vocalic pattern, $<* y u$-kattib indicates that this inflectional form arose by the grammaticalization of the derivational pattern of the factitive; cf. Akkadian $u$-parris).

On the other hand, Aramaic and Hebrew have not created (or rather 're-created') the Proto-Semitic perfect on analytic basis (this happened only much later on in Neo-Aramaic dialects, see GoldEnBERG 1992). The development of the 'be'-perfect is a salient innovation of the New Stage, represented by Classical Arabic.

\section{NEW STAGE IN SEMITIC}

During the New Stage represented by Classical Arabic the fundamental innovation was the rise of the analytic perfect of the type kān-a (qad) katab-a 'he had written') and the resulting system can be portrayed as recreating the old three-way aspectual system on an analytic basis:

Classical Arabic aspectual system

$\begin{array}{lll}\text { Imperfective } & \text { Completive } & \text { Perfect } \\ \text { ya-ktub-u } & \text { kataba } & \text { kāna (qad) kataba } \\ \text { 'he writes/will write' } & \text { 'he wrote' } & \text { 'he had written' }\end{array}$

Ethio-Semitic represented by Geez innovated in the same fashion by combining the verb 'to be' in the past (either hallawa or kona 'he was') with the completive category:

Geez aspectual system

$\begin{array}{lll}\text { Imperfective } & \text { Completive } & \text { Perfect } \\ \text { yə-kattəb } & \text { kataba } & \text { kona kataba } \\ \text { 'he writes/will write' } & \text { 'he wrote' } & \text { 'he had written' }\end{array}$

In Central Semitic languages there are two morphological relics of the Proto-Semitic aspectual system where the ablauted prefixal form (of the type Akkadian type $i$-prus, Arabic 
$y a-k t u b$ ) functioned as the completive category (HeTzRon's 1969 Proto-Semitic *yá-qțul). In Arabic this form (called jussive) is used after the negative particle lam, e.g. lam yaktub 'he didn't write'/ 'he hasn't written') and in the prohibitive (= negative imperative), e.g. la taktub 'don't write'.

The rise of the analytic perfect based on the combination of the finite form of the main verb in the completive with the copula kān- $a$ 'he/it was' represents a salient innovation of Arabic and Ethio-Semitic (Geez). This construction featuring double agreement never developed in Mishnaic Hebrew. In Aramaic, as we saw in (12), it is possible to combine the participle finitized by personal clitics with the copula in expressions of habituality. Aramaic thus stands a half way between Mishnaic Hebrew and Arabic:

Analytic constructions with the copula

$\begin{array}{lll}\text { Mishnaic Hebrew } & \text { hāȳ̄-ț̄i Pōmēr } & \text { 'I used to say' (i.e. not *hāȳ̄-tī Pāmar-tī) } \\ \text { Middle Aramaic } & \text { həwāh (kāe)Pāmē-nā } & \text { 'I used to say' (no agreement in person) } \\ \text { Classical Arabic } & \text { kun-tu (qad) qul-tu } & \text { 'I had said' (with agreement in person) }\end{array}$

The structure $k \bar{a} n-a \ldots \mathrm{X} k a t a b-a$ 'it was ... X wrote' can be derived from pseudo-relative clauses of the type kānat ummuhu qad katabat 'his mother was [a woman/one who] had already written' with the relative clause left unmarked when referring to an indefinite antecedent; in diachronic terms this structure could be an initial input to the grammaticalization process which ended up as the past perfect kān-a qad katab-a 'he had written'. In Geez there is a parallel construction combining the verb kon- $a$ 'he/it was' with the main verb in the completive kon- $a$ katab- $a$ 'he had written' (in addition, Geez features another formation for the expressions of anteriority based on the combination of the verb nabara 'he remained' with the main verb in the semi-finite gerund, see WENINGER 1999: 32).

$$
\begin{aligned}
& \text { li=ðālika kānat iðā daxalat ... qāma ilayhā } \quad \text { [Haikal; in CANTARINo 1974: 71] } \\
& \text { for this reason be+COMPL+3SG/F when enter+COMPL+3SG/F rise+COMPL+3SG/M to=her } \\
& \text { 'For this reason, whenever she (had) entered ... he used to stand up ...' }
\end{aligned}
$$

In Arabic the anteriority is emphasized by the particle qad.

$$
\begin{aligned}
& \text { kānat ummuhu qad samiSat șawta sayyidinā [Husayn; in CANTARINo 1974: 72] } \\
& \text { be+COMPL+3SG/F mother=his PRT hear+COMPL+3SG/F voice+ACC master+GEN=our } \\
& \text { 'His mother had already heard the school teacher's voice' }
\end{aligned}
$$

As shown in (25) and (26) the auxiliary kān- $a$ and the main verb are not necessarily adjacent; their semi-dependent status is reflected above all in their "disagreement" of the

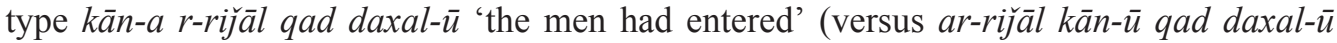
'as for the men they had entered'). In other words, the grammaticalization process has not completed its course; the analytic perfect in Arabic has not reached the status of the compound perfect in IE languages where the auxiliary ('have' or 'be') and the participial form of the main verb are typically adjacent (e.g. Modern Greek o Ianis íx-e yrap-si or íxe rráp-si $o$ Ianis 'John had written' but NOT *ixe o Ianis yráp-si).

The formation of the analytic present perfect with the auxiliary in the imperfective (competing with the present perfect expressed by participle huwa kātib 'he has written') and the future perfect represent further development of this construction by means of auxiliation: 
The rise of the analytic perfect in Classical Arabic:

$\begin{array}{ll}\text { katab-a } & \text { 'he wrote' } \\ \text { kān-a katab-a } & \text { 'he had written' (also 'he would have written') } \\ \text { ya-kūn-u katab-a } & \text { 'he has written' (also huwa kātib, see (33 b)) } \\ \text { sa(wfa) ya-kūn-u katab-a } & \text { 'he will have written' }\end{array}$

The formation of the future perfect exploits another innovation of Classical Arabic, namely the introduction of the future tense particle $s a(w f a)$. After all these innovations the aspectual system of Classical Arabic, diagrammed in (22) in its incipient stage, can be portrayed as possessing a three-way temporal contrast shown in (28); the formations of the perfect can be reinforced by the emphatic particle qad.

\begin{tabular}{|c|c|c|c|}
\hline & Present & Past & Future \\
\hline \multirow[t]{2}{*}{ Imperfective } & ya-ktub-u & kāna ya-ktub-u & sa=ya-ktub-u \\
\hline & 'he writes/is writing' & 'he was writing' & 'he will write' \\
\hline \multirow[t]{2}{*}{ Completive } & & katab-a & \\
\hline & & 'he wrote' & \\
\hline \multirow[t]{4}{*}{ Perfect } & ya-kūn-u (qad) katab-a & kān-a (qad) katab-a & sa=ya-kūn-u (qad) katab-a \\
\hline & 'he (always) has written' & 'he had written' & 'he will have written \\
\hline & & kāna sa=yaktubu & \\
\hline & & 'he was going to write' & \\
\hline
\end{tabular}

(Medieval Greek and Old Slavic offer close typological parallels in their keeping the old imperfective (Present and Imperfect) and perfective (Aorist) categories and forming the perfect on an analytic basis).

As far as the modal forms are concerned, the jussive is the main exponent of modality in Semitic languages, comparable with the precative of Akkadian and optative of Greek. Compared with Greek the Classical Arabic modal system appears to be more limited in its morphology. As we saw in (2) Greek displays its modal forms (subjunctive and optative) in all the three aspectual categories; in Classical Arabic the subjunctive can be formed only in the imperfective $y a-k t u b-a$ 'that he write' and in the perfect ya-kūn-a qad kataba 'that he have written'; their jussive counterparts remove the suffix $-a$ in the imperfective form( $f a l=) y a-$ $k t u b$ 'may he write', and their analytic counterparts are available in the perfect: and ya-kun qad kataba 'may he have written'. In addition, however, in Arabic the completive category, katab-a, can also be used modally to express (un)real wishes with a limited number of verbs, such as 'have mercy', 'honor', 'bless', 'live'. All these forms are surveyed in (29):

\begin{tabular}{|c|c|c|c|}
\hline \multirow{3}{*}{ Subjunctive } & Imperfective & Completive & Perfect \\
\hline & ya-ktub-a & & ya-kūn-a qad kataba \\
\hline & 'that he write' & & 'that he have written' \\
\hline \multirow[t]{2}{*}{ Jussive } & $(\mathrm{fal}=)$ ya-ktub & ৎāš-a & $(f a l=)$ ya-kun qad kataba \\
\hline & 'may he write' & 'may he live' & 'may he have written' \\
\hline
\end{tabular}

The use of the completive to express wishes, such as $\{\bar{a} \bar{s}-a$ ' $l=$ malik '[long] live the king', akram- $a=k a$ ' $l=l \bar{a} h u$ 'May God honor you' parallels typologically the use of stative 
for the same purpose in Akkadian (in 3). In Akkadian the modal use of stative can be reinforced by the particle $l \bar{u}$ (as in $l \bar{u}$ balit) 'may he live'), in Arabic by the particle layta, as in layta=hu kāna hunā 'I wish he were here' 'If only he were here'.

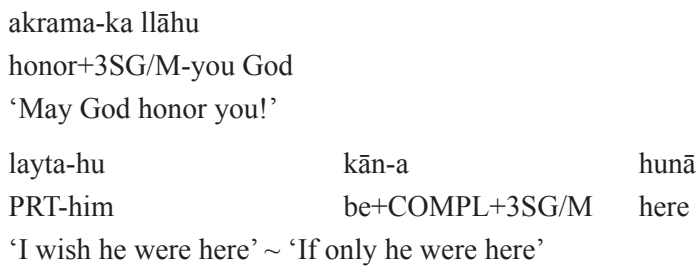

The completive is also used in the protasis and apodosis of conditional sentences with particles law 'if' and la 'truly', respectively:

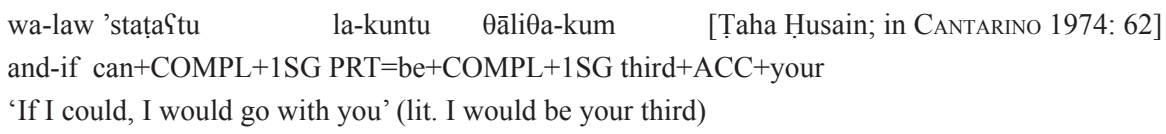

In its expressions of the irrealis Arabic (la=qul-ta 'you would say' 'you would have said') resembles Ancient Greek which uses the indicative forms (of either the imperfect eleges an 'you would say' or aorist éleksas an 'you would have said'), while Latin uses the subjunctive forms (diceres or dixisses). Another way of forming the conditional (in colloquial) is to combine the past auxiliary kāna with the future tense $k \bar{a} n s a=y \partial k t o b$ he would write'. (This strategy is reminiscent of that used for the formation of the conditional in IE

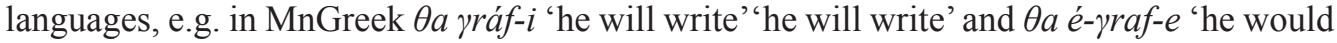
write'). In Classical Arabic, as we saw in (28), kāna sa=yaktubu, is used for the future in the past 'he was going to write'.

In negative statements the three-way aspectual contrast is given prominence in the shape of three different negative particles: $l \bar{a}, m \bar{a}$ and $l a m$. The negative particle $l \bar{a}$ is used with the imperfective (with reference to the present or future). $M \bar{a}$, the other negative particle, is very common in colloquial Arabic, and is used with the completive to express past completed events (but also present perfect with stative verbs). The negative particle lam combines with the jussive (the apocopated form) to express both aspects: past completive and (present perfect). In the pluperfect both options ( $m \bar{a}$ kāna and lam yakun) are available.

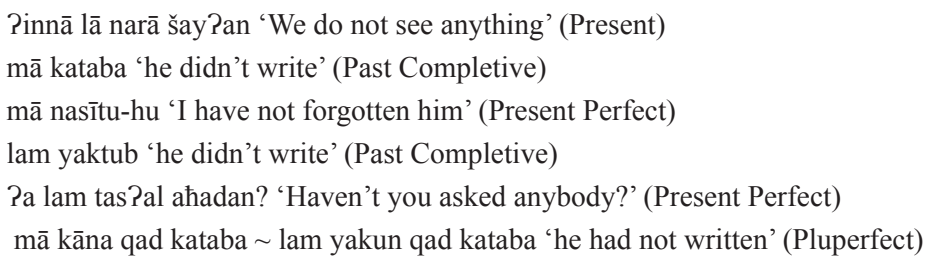

According to Sībawaihi (Vol. I: 460), the difference between the aspectually ambiguous lam ya-fSal 'he didn't do (it)' and 'he hasn't done it' and ma faSal-a 'he didn't do (it)' is rather that of emphasis, esp. when an oath word wallāhi 'by God' is inserted'. Accordingly, the difference between these two is in the degree of certainty: (wallāhi) ma faSal=hu '(By God), he really didn't do it' or 'He did NOT do it' (versus lam ya fYal=hu 'he didn't do it'. 
In spoken Arabic the subtle contrast of (past) completive versus (present) perfect is implemented by the completive versus the present participle with active verbs (in keeping with its meaning of the present state resulting from the past event). Consider the following minimal pair of sentences from Moroccan Arabic:

ana ktebt $\begin{aligned} & \text { Clih "felfel" } \\ & \text { I }\end{aligned}$ write+COMPL+1SG
on-it "pepper"
$\begin{array}{ll}\text { 'I wrote "pepper" on it' -> [and perhaps the label is no longer there] } \\ \text { ana kateb } & \text { Clih "felfel" } \\ \text { I } & \text { on-it "felfel" }\end{array}$
'I have written "pepper" on it' -> [and the label is still there]

(33 a) expresses a past completed event without stipulating that the result of the past action still obtains in the present, while (33 b) exploiting the present participle expresses unambiguously the present result of the past action.

\section{CONCLUSIONS AND DESIDERATA FOR FURTHER RESEARCH}

In Section 1. I emphasized that the contrastive studies of the verbal systems of AfroAsiatic and Indo-European languages have to pay due attention to the crucial theoretical distinction of perfect and perfectivity (I am planning to revisit this issue in another theoretically oriented paper). In Section 2. I used the model of our study of tense and aspect in Indo-European languages (HEwson \& BUBENIK 1997) which allows to distinguish five major aspectual categories (prospective, inceptive, imperfective, perfective and perfect) within "Event Time". In I introduced typological parallels with Ancient Greek whose aspectual system is based on the double binary system of [perfect] vs. [-perfect], the latter subdivided into the familiar opposition of imperfective vs. perfective. For Semitic I adhered to the view that the familiar morphological opposition katab-a versus $y a-k t u b-u$ is best described by double temporo-aspectual labels past/completive versus non-past/imperfective (paralleling CoHEN's 1989 “accompli” vs. "inaccompli”). In Section 3. Akkadian (the Old Stage of Semitic languages) was introduced as a representative of a three-way aspectual system i-parras - i-prus - i-p-ta-ras (imperfective - completive - perfect). In Section 4. the Middle Stage - represented by Mishnaic Hebrew and Middle Aramaic - witnessed the rise of temporal distinctions by means of the copula in combination with the participle; in a sense the old aspectual system was temporalized. In Section 5. the appearance of the analytic doublefinite perfect in Arabic (of the type kuntu katabtu 'I had written) was described as the most significant innovation during the New Stage. It is not to be found in the other two Central Semitic languages - Hebrew and Aramaic. Old (Biblical) Hebrew preserved an earlier state of affairs in relying exclusively on the ambiguous 'neo-perfect' (of the type kātáb-tī) to express both the perfect and completive aspect; but we also saw a significant relic of the earlier completive category in the construction of "the consecutive imperfect" (of the type way $=y i k t \bar{o} \underline{b}$ 'and he wrote') and the innovative "consecutive imperfect" ( $w \partial=\underline{k} \bar{a} t a \underline{b-t}$ ' $\bar{l}$ ' and I will write'). Classical Arabic - representing the New Stage - completely remodeled the old aspectual system by creating the progressive aspect and analytic perfect on an analytic basis and forming the future by the particle $s a(w f a)$. These aspectual formations are double 
finite with both the copula and the main verb inflected: kāna yaktubu lit. he-was he-writes $>$ 'he was writing'. As was shown in (28) the innovative future in combination with these analytic formations establishes the Arabic verbal system as forming three tenses (present past - future) in two analytic aspects (progressive and perfect) in both non-modal and modal forms (jussive and subjunctive).

\section{REFERENCES AND BASIC BIBLIOGRAPHY}

Abdel-Massin Ernest T. 1973. An Introduction to Moroccan Arabic. Ann Arbor: The University of Michigan.

Abu-Chacra Faruk. 2007. Arabic. An Essential Grammar. London: Routledge.

Anstey Matthew P. 2009. "The Biblical Hebrew qatal Verb: A Functional Discourse Grammar Analysis." Linguistics 47(4), 825-844.

BaHLoul Maher. 2008. Structure and Function of the Arabic Verb. London: Routledge.

Bateson Mary C. 2003. Arabic Language Handbook. Washington, DC: Georgetown University Press.

Bender M. Lionel et al. (eds.). 2003. Selected Comparative-Historical Afrasian Linguistic Studies. Munich: Lincom Europa.

Brockelmann Carl. 1908-1913 (reprint 1982). Grundriss der vergleichenden Grammatik der semitischen Sprachen, 2 vols. Berlin: Reuther \& Reichard.

BRustad Kristen E. 2000. The Syntax of Spoken Arabic. Washington, D.C.: Georgetown University Press.

Bubenik Vit. 2003. "Ablaut and Aspect in Akkadian and Proto-Semitic.” In: Bender et al. 2003: 193-208.

CAntarino Vicente. 1974. Syntax of Modern Arabic Prose (I-III). Bloomington-London: Indiana University Press.

CoHen David. 1984. "La phrase nominale et l'évolution du système verbal en sémitique". Collection Linguistique LXII. Paris: Société linguistique.

Cohen David. 1989. L'aspect verbal. Paris: Presses Universitaires de France.

Comrie Bernard. 1976. Aspect. Cambridge: Cambridge University Press.

ComRIE Bernard. 1991. "On the Importance of Arabic for General Linguistic Theory." In: ComRIE \& EID 1991: $3-30$.

Comrie Bernard, Eid Mushira (eds.). 1991. Current Issues in Linguistic Theory. Amsterdam: Benjamins.

Cowell Mark. 1964. A Reference Grammar of Syrian Arabic. Washington DC: Georgetown University.

DAHL Östen (ed.). 2000. Tense and Aspect in the Languages of Europe. Berlin: Mouton de Gruyter.

DAhLgRen Sven-Olof. 2009. "The Relevance of Tense and Aspect in Semitic Languages: The Case Hebrew and Arabic.” In: JosepHSON \& SÖHRMAn 2009: 221-247.

DiAKONOFF Igor. 1988. Afrasian Languages. Moscow: Nauka.

Eвert Karen H. 2000. “Aspect in Maltese.” In: Dahl 2000: 753-788.

EISELE John. 1999. Arabic Verbs in Time: Tense and Aspect in Cairene Arabic. Wiesbaden: O. Harrassowitz.

EISELE John. 2005. “Aspect.” In: Versteegh et al. 2005: 195-201.

FisCHER Wolfdietrich. 2002. A Grammar of Classical Arabic. New Haven-London: Yale University Press.

Fleisch Henri. 1957. "Etudes sur le verbe arabe." Mélanges Louis Massignon II, 153-181. Damascus: Institut Français de Damas.

Fradkin Robert A. 1985. Markedness Theory and the Verb System of Russian and Arabic: Aspect, Tense and Mood (unpublished thesis, Indiana University).

Gianto Agustinus (ed.). 2005. Biblical and Oriental Essays in Memory of William L. Moran. Roma: Pontificio Istituto Biblico.

GoldenBerg Gideon. 1992. "Aramaic Perfects.” Israel Oriental Studies 12: 113-137.

GrotzFeld Heinz. 1965. Syrisch-arabische Grammatik. Wiesbaden: Harrassowitz.

Gzella Holger. 2004. Tempus, Aspekt und Modalität im Reichsaramäischen. Wiesbaden: Harrassowitz.

HaRrell Richard. 1962. A Short Reference Grammar of Moroccan Arabic. Washington DC: Georgetown University.

Hetzron Robert. 1969. “The Evidence for Perfect *yáqtul and jussive * yaqtúl in Proto-Semitic.” JSS 14, 1-21.

Hetzron Robert (ed.). 1997. The Semitic Languages. London: Routledge. 
Hewson John, Bubenik Vit. 1997. Tense and Aspect in Indo-European Languages: Theory, Typology, Diachrony. Amsterdam-Philadelphia: John Benjamins.

Huehnergard John. 2005. "Features of Central Semitic." In: Gianto 2005: 155-203.

Josephson Folke, SöHrman Ingmar (eds.). 2009. Interdependence of Diachronic and Synchronic Analyses. Amsterdam: Benjamins.

KurYŁowicz Jerzy. 1973. "Verbal Aspect in Semitic." Orientalia 42, 114-120.

LeSLAu Wolf. 1989. Concise Dictionary of Ge 'ez. Wiesbaden: Otto Harrassowitz.

LIPIŃsKi Edward. 2001. Semitic Languages Outline of a Comparative Grammar. Leuven: Peeters.

McGregor R.S. 1977. Outline of Hindi Grammar. Delhi: Oxford University Press.

Mitchell T.F., El-Hassan S.A. 1994. Modality, Mood and Aspect in Spoken Arabic With Special Reference to Egypt and Levant. London: Kegan Paul International.

Reichenbach Hans. 1947. Elements of Symbolic Logic. New York: Collier-Macmillan. (Repr. New York: Free Press, 1966).

Rogland Max F. 2003. Alleged Non-past Uses of Qatal in Classical Hebrew. Assen: Van Gorcum.

RuBin Aaron. 2005. Studies in Semitic Grammaticalization. Harvard Semitic Studies 57. Harvard Semitic Museum: Eisenbrauns.

Segal M.H. 1957. A Grammar of Mishnaic Hebrew. Oxford: Clarendon Press.

Von Soden Wolfram. 1952. Grundriss der akkadischen Grammatik. Rome: Pontificium Institutum Biblicam.

Vendler Zeno. 1967. Linguistics in Philosophy. Ithaca, NY: Cornell University Press.

Versteegh Kees et al. (eds.). 2005. Encyclopedia of Arabic Language and Linguistics. Leyden: E.J. Brill.

WenINGER Stefan. 1999. Gaৎəz. Munich: Lincom Europa.

WoIDICH Manfred. 1975. "Zur Funktion des aktiven Partizips im Kairenischen-Arabischen." ZDMG 125, $273-$ 293. 